\title{
Application of Flow Methods for Material and Financial Resources Management to Forecast Oil Production in Russia
}

\author{
Aydar M. Tufetulov ${ }^{1}$, Shamil M. Valitov ${ }^{1} \&$ Amur F. Yartiev ${ }^{2}$ \\ ${ }^{1}$ Kazan Federal University, Institute of Economics and Finance, Kazan, Russia \\ 2 TatNIPIneft Tatar Oil Research and Design Institute of OAO TATNEFT, Bugulma, Russia \\ Correspondence: Aydar M. Tufetulov, Institute of Economics and Finance, Kazan (Volga Region) Federal \\ University, Butlerov st. 4, 420012, Kazan, Russia. Tel: 843-291-1369; 8-987-296-02-92. E-mail: \\ ajdar-t@yandex.ru
}

Received: August 25, 2014 Accepted: September 19, 2014 Online Published: November 14, 2014

doi:10.5539/ass.v10n23p60 URL: http://dx.doi.org/10.5539/ass.v10n23p60

\begin{abstract}
The paper considers the impact of flow methods on long-term development of oil extracting industry, the impact being associated with mineral resources production tax variation. Six oil production scenarios for Russia have been considered, comparative analysis of these scenarios is presented. By the end of the calculation period, the scenario that provides for 5\% decrease of tax burden closely approximates the scenario of oil production under effective taxation system In terms of budget receipts volumes. The scenario with mineral resources production tax rate increase is the worst in terms of oil industry growth leading to the industry collapse. According to this scenario, an operating company's tax burden increases to $78 \%$. So far, the world practice has not witnessed economic growth under conditions of taxes as high as this; furthermore, taxation history testifies that too high taxes have not been paid. In terms of oil industry growth, the scenario that provides for 5\% decrease of tax burden is the most credible and promising, provided the released flows are invested in production. The same level of tax burden decrease (5\%) is required to attain oil production levels in Russia in 2018-2020s according to the 2030 Development Strategy.
\end{abstract}

Keywords: effective taxation system, flow investments, expenses, flow, flow method, mineral resources production tax, oil production, tax burden, tax burden threshold

\section{Introduction}

Steady growth of population is associated with increase of natural resources consumption. For the last 50 years, the world population has grown more than three-fold, from 2 to 7 billion people. It is estimated that population growth will continue to become 9 billion by 2050. Some analysts hold that the Earth's resources will not suffice to provide more than 8 billion people. It should also be remembered that population of countries with developing economies want higher standards of living and this can only be done with higher per capita energy use. (World Population in 2011. - URL: http://gtmarket.ru/news/state/2011/10/31/3701)

The most powerful driving forces of energy demand are population growth and increased revenue. According to British Petroleum "World Energy Outlook 2030", starting with the twentieth century, the world population has increased more than 4 times, the real income - 25 times, and the primary energy consumption - 22.5 times. (BP Statistical Review of World Energy. - URL: http://bp.com/statisticalreview)

To date, no alternative source of energy can replace the need for hydrocarbons. Renewable energy (solar, wind, tides, thermal waters, hydroelectric power plants, etc.) are some successful examples of implementation, but their widespread use is unpromising because of the high cost of implementation, low efficiency and limited territorial locations of energy production. Nuclear energy alone cannot provide the necessary energy requirements, and after the recent events at the Fukushima nuclear power plant (Japan) the attitude to this type of energy has been negative.

Despite the efforts and achievements of the world fundamental science to develop new sources of energy, all the world's energy agencies recognize that in the first half of the twenty-first century, major energy carriers in the world are oil and gas. 
It has been generally recognized that oil, being a unique fuel, is a nonrenewable natural energy source with depleting reserves and irregular consumption. World hydrocarbon resources are not evenly spread, both in terms of area and stratigraphic sequences. It would seem that the global distribution of oil consumption should follow the natural law of irregular distribution of hydrocarbon resources; however this is not the case, which is evident from oil consumption trends in the USA. If we assume that all countries reached the US level of average per capita consumption, world oil production would have to be increased five-fold. Even considering rapid growth of technology we are all witnessing, the present-day consumption pattern would require resources of several planets similar to Earth for the above assumption to become true.

It is known that energy once used cannot be reused and in such a closed circuit as the Earth the entropy is steadily increasing, so even the recent tendency to energy sources appreciation will not turn energy resources deficiency into overabundance (Lloyd, 1987).

John Maynard Keynes considered the economy not as "the science of thinking in terms of models," but as "the art of choosing the appropriate models." He described government intervention as a necessary condition for the continued existence of a system based on free enterprise. Without denying the role of the state, the Polish economist Michal Kalecki expected not only full employment, but also a more rational allocation of resources, in terms of the poorer classes from government intervention. American experts Michael H. Mescon., Michael Albert and Franklin Khedouri defined power as the ability to influence the behavior of other people. (Mescon, Albert, \& Khedouri, 1997)

Planning and forecasting are the basis of management, and Fayol Henry, one of the outstanding representatives of management of the first quarter of XX-century, who developed the basis of the administrative approach to the management, paid special attention to planning and forecasting and emphasized the need for short-term and long-term planning. Sunita Kikeri, Thomas Kenyon, Vincent Palmade considered implementation and monitoring as an integral part of the production process (Kikeri, Kenyon, \& Palmade, 2007).

In accordance with the concept of Frank H. Knight it is uncertainty that is a source of net profit or loss. (Knight, 1921) Eugene F. Brigham, Louis C. Gapenski considered the basic concepts of the theory of capital structure, financial analysis techniques, evaluation criteria for investment projects (Brigham \& Gapenski, 2004).

The Swedish economist Gunnar Myrdal conducted a deep analysis of the interdependence of economic, social and institutional phenomena. (Myrdal, 1939) Joan Violet Robinson expanded Keynesian economic theory as applied to a long-term period (Robinson, 1956).

Robert W. Clower, Douglass Cecil North, Igor Ansoff, Jan Tinbergen were involved in modeling with the analysis of economic processes. Peter Ferdinand Drucker formulated the theory of global market (Drucker, 1946), and William F. Sharpe, Gordon J. Alexander, Jeffery V. Bailey considered methods of investment management, stating the challenges of global of investment (Sharpe, Alexander, \& Bailey, 1946).

Jay W. Forrester, the founder of System Dynamics theory, considered natural resources as a flow that decreases rate of its consumption, while he referred social systems to the class of complex counterintuitive nonlinear systems with multiple feedback loops (Lloyd, 1987). Present-day problems of national economy development are analyzed by a well-known economist V.V. Ivanter (Forrester, 2003).

In a competitive energy market environment, high profitability of business activities is the main objective of oil industry development. Profitability, along with other factors (oil production, investments, tax burden etc.) is governed, largely by effectiveness of management of material and financial resources.

When addressing issues associated with management of financial resources in oil industry we should consider the specifics that determine basic business activities, i.e. geologic exploration, well drilling and completion, production of oil and associated gas, flow lines and trunk pipelines, crude oil and gas treatment and refining, oil sale, construction of costly production and infrastructure facilities based on innovative technologies or the latest world technological solutions.

\section{Materials and Methods}

One of the most effective tools of management of material and financial resources is a flow method aimed at expenses optimization and innovative development of production. Flows of any operating company's resources, regardless of their nature, are possible during concrete periods of time, besides, a flow has a start point and a specific destination, moments of beginning and ending, intensity, and other inherent parameters characteristic of cash flows. 
The concept of "flow" has been studied in detail from the standpoint of economics, mathematics, and logistics. It exists as a process at a certain interval and is determined for a specific period of time. A flow is an economic category, which characterizes the system of structurally interrelated elements perceived as a whole and which undergo dynamic changes within a certain period of time.

Despite the specific features of work orientation in the divisions of oil industry, they share the application of flow approach methodology in the field of financial management. The methodology comes from the following premise: flow of funds at enterprises, regardless of their profile, is carried out in specific time periods, and the flow has a starting point and a destination, a moment of start and end, intensity and a number of other indicators of cash flow.

Multistage and pluridisciplinary process of oil production offers considerable scope for detailed analysis of the role of individual elements of the process, operative and strategic planning of operational activity. Flow approach is, in large measure, an innovative idea, however, flows should be considered as a methodology and as an independent aspect of management comprising specific and expert capabilities, methods of visual imaging of information and tools to solve concrete tasks. Flow methods can be efficiently used to solve the tasks of operative and strategic planning and financial management.

In the context of oil production, any operating company's resources' flows can be narrowed down to income inflows and outflows. It is noteworthy that a major portion of an outflow for a license holder makes an inflow for a government budget in form of taxes and deductions. The famous Laffer curve drawn by the American economist Arthur B. Laffer shows that under certain conditions decrease of tax rates increases government's tax revenues (Ivanter \& Ksenofontov, 2012).

When an operating company's tax burden decreases, a portion of the outflow (absolute value of tax burden) becomes of a reverse type and can be invested into production development. An operating company's tax burden increase leads to reduction of investor's income inflow and decreases operating capital invested in improvement of productive capacities and production innovative development (Laffer, 1979).

At close consideration, it is evident that the specifics of operating companies' taxation system change flows directions repeatedly. For example, decrease of mineral resources production tax leads to increase of the company income tax, which, in its turn, leads to decrease of company taxable base. In fact, flows of a company's operating activity in accordance with the effective taxation system are of the oppositely-directed reverse type (Table 1).

Table 1. Impact of reverse-type legal acts on profit and revenue

\begin{tabular}{|c|c|c|c|c|c|}
\hline \multirow{2}{*}{ Federal Law } & \multirow{2}{*}{ Application } & \multicolumn{2}{|c|}{ Impact on profit } & \multicolumn{2}{|c|}{ Impact on revenue } \\
\hline & & Operator & Government & Operator & Government \\
\hline $\begin{array}{l}\text { Federal Law No.151 } \\
\text { as of } 27 \text { July } 2006\end{array}$ & $\begin{array}{l}\text { Cumulative production of } \\
\text { recoverable reserves more than } \\
30 \%\end{array}$ & increases & increases & increases & decreases \\
\hline $\begin{array}{l}\text { Federal Law No.151 } \\
\text { as of } 27 \text { July } 2006\end{array}$ & $\begin{array}{l}\text { In-situ oil viscosity more than } \\
200 \mathrm{mPa} \cdot \mathrm{s}\end{array}$ & increases & increases & increases & decreases \\
\hline $\begin{array}{l}\text { Federal Law No.151 } \\
\text { as of } 27 \text { July } 2006\end{array}$ & $\begin{array}{l}\text { Hydrocarbon fields in Extreme } \\
\text { North and Far East }\end{array}$ & increases & increases & increases & decreases \\
\hline $\begin{array}{l}\text { Federal Law No.307 } \\
\text { as of } 11 \text { Nov } 2010\end{array}$ & Change of standard taxation rate & decreases & decreases & decreases & increases \\
\hline $\begin{array}{l}\text { Decree No.716 as of } \\
26 \text { Aug } 2011\end{array}$ & Oil and oil products for export & increases & increases & increases & decreases \\
\hline $\begin{array}{l}\text { Federal Law No. } 258 \\
\text { as of } 21 \text { July } 2011\end{array}$ & $\begin{array}{l}\text { New fields with production of } \\
\text { OOIP less than } 5 \%\end{array}$ & increases & increases & increases & decreases \\
\hline $\begin{array}{l}\text { Executive Order No. } \\
700-p \text { as of } 3 \text { May } \\
2012\end{array}$ & $\begin{array}{l}\text { Tight oil reservoirs with } \\
\text { permeability below } 2 \mathrm{md}\end{array}$ & increases & increases & increases & decreases \\
\hline $\begin{array}{l}\text { Federal Law No. } 213 \\
\text { as of } 23 \text { July } 2013\end{array}$ & $\begin{array}{l}\text { Heavy oil with in-situ oil } \\
\text { viscosity more than } 1000 \mathrm{mPa} \cdot \mathrm{s}\end{array}$ & increases & increases & increases & decreases \\
\hline $\begin{array}{l}\text { Federal Law No. } 263 \\
\text { as of } 30 \text { Sept } 2013\end{array}$ & Change of standard taxation rate & decreases & decreases & decreases & increases \\
\hline $\begin{array}{l}\text { Federal Law No. } 263 \\
\text { as of } 30 \text { Sept } 2013\end{array}$ & $\begin{array}{l}\text { Change of calculation of export } \\
\text { tax rate }\end{array}$ & increases & increases & increases & decreases \\
\hline
\end{tabular}


The authors suggest the following interpretation of a reverse-type flow. This is an economic category, which characterizes the system of elements interaction, perceived as whole and undergoing dynamic changes in time and structure. Therefore, from our point of view, a reverse-type flow should be regarded as a controlled subsystem within the general management system of an enterprise, which has been altered by four variables time, space, quantity and quality.

Length, start and end points are typical for the spatial variation of the reverse type flow; duration - for the time variable; stock, volume component structure - for the quantitative one. The reflection of qualitative states in the oil production is observed according to the balance of supply of hydrocarbons to different markets (near and far abroad, domestic market). Each delivery from the overall balance of the enterprise has its own tax system and more specific cost system.

In our opinion, a reverse-type flow should be understood to mean a specific system of taxation applied to operating companies. We believe, a new indicator should be introduced, namely, tax burden threshold per sale (production) of 1 tonne of oil.

Tax burden threshold per production of 1 tonne of oil is a multifactorial concept that determines a critical point, or threshold, of long-term innovative funding. This threshold value is determined based on the cost-benefit analysis, potential for further reserve replacement to maintain current stable oil production, as well as potential for further oil production increase in view of growing expenses associated with application of innovations in oil extracting industry.

It is quite possible to find an optimal value of tax burden, which whereas providing an operating company with more opportunities for innovative development and increased oil production, will minimize lost budget receipts, which would lead in the long run to increased tax revenues.

For the purpose of flow methods' analysis, let us consider an oil company's operating expenses with $60 \%$ of mineral resources production tax in the product cost structure (Figure 1).

Practically all official legal acts decrease, to a greater or lesser degree, tax burden on an operating company and build a basis for future production growth.

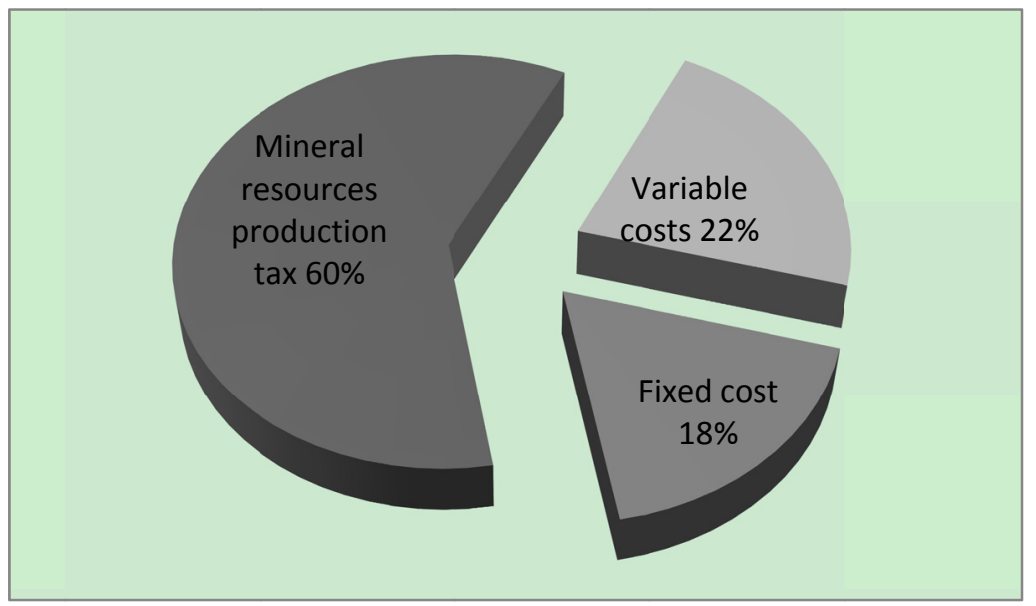

Figure 1. OPEX distribution

\section{Results}

Let us analyze the impact of the flow method on oil producing industry growth in Russia. As an information source, we will use "Energy Strategy of Russia for the Period till 2030" development strategy (hereinafter referred to as the 2030 Development Strategy) (Yartiev, 2011) (Energy Strategy of Russia for the Period till 2030), even though its authors admit that in terms of capital investments in industry growth and resource replacement, oil extracting industry stopped well short of the minimum level a few decades ago, which means that there is no need to hold back investors providing capital for industry growth and improvement of production management.

Model calculations of investment flows resulting from differentiation of mineral resources production tax make it possible to determine oil industry trends. The developed dynamic model of oil production considers six scenarios of long-term oil production under different capital investment conditions. 
The methodology of evaluation of production effectiveness and flow management realized in the model is based on the comprehensive, multidimensional, and multilevel approach to the effectiveness of production management. The methodology accounts for interaction of numerous criteria and factors contributing to final result in view of the future industry growth, making, thus, possible to disclose principal negative trends and to address them.

We extrapolate the 2030 Development Strategy data to the forecast of oil production provided tax burden has been changed. Figure 2 shows oil production trends according to different capital investments and resource replacement scenarios.

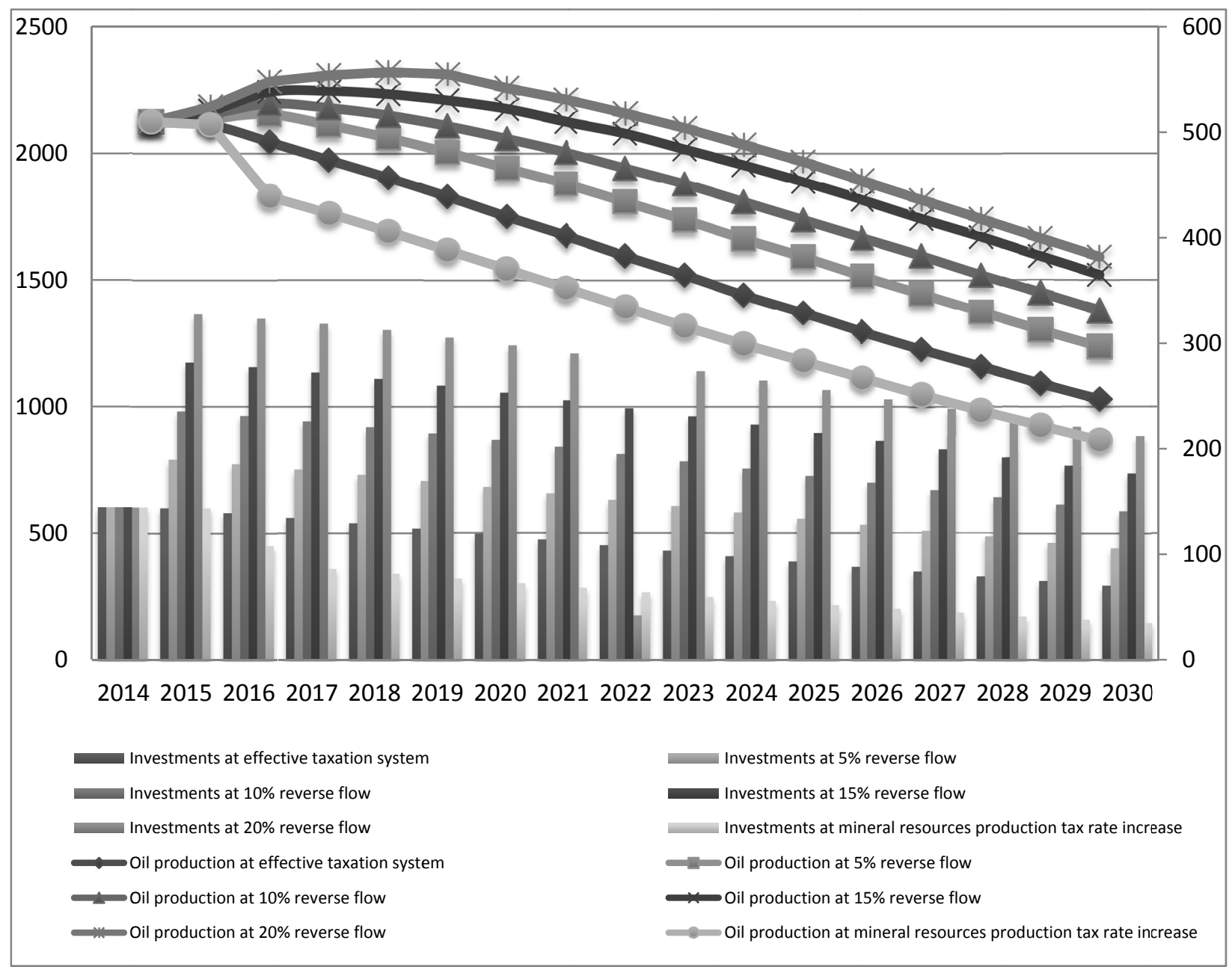

Figure 2. Impact of flow method on oil production

We have considered the following six oil production scenarios in Russia:

- under effective taxation system

- subject to an oil operating company's tax burden decrease by $5 \%$

- subject to an oil operating company's tax burden decrease by $10 \%$

- subject to an oil operating company's tax burden decrease by $15 \%$

- subject to an oil operating company's tax burden decrease by $20 \%$

- subject to an oil operating company's tax burden increased resulting from mineral resources production tax rate increase 
Oil production scenario under effective taxation system yields descending trend with annual oil output of 206 million tonnes in 2030. Decrease of an operating company's tax burden will yield increase of oil production in the middle term.

Decrease of an operating company's tax burden resulting from reverse flow will yield increase of oil production in the middle term.

The scenario with mineral resources production tax rate increase yields the most dramatic decline of annual oil production with the difference between scenarios as high as 174 million tonnes of oil per year.

The difference in oil output can be accounted for by different scenarios of reverse-type capital investments in production growth and maintaining current oil production level with resource replacement in the long term.

The value of an operating company's tax burden directly influences the value of capital investments in production growth. The scenario that provides for $20 \%$ decrease of tax burden yields the highest value of capital investments (about USD 1 trillion) however this value is two times less than that of the 2030 Development Strategy. Maximum difference between annual capital investments by the end of the calculation period (2030) according to the presented scenarios may reach RUB billion 664.

The scenario that provides for $15 \%$ decrease of an operating company's tax burden matches the 2030 Development Strategy figures most closely, however the government budget needs tax receipts at the running period, so this is not an optimal scenario either (Figure 3).

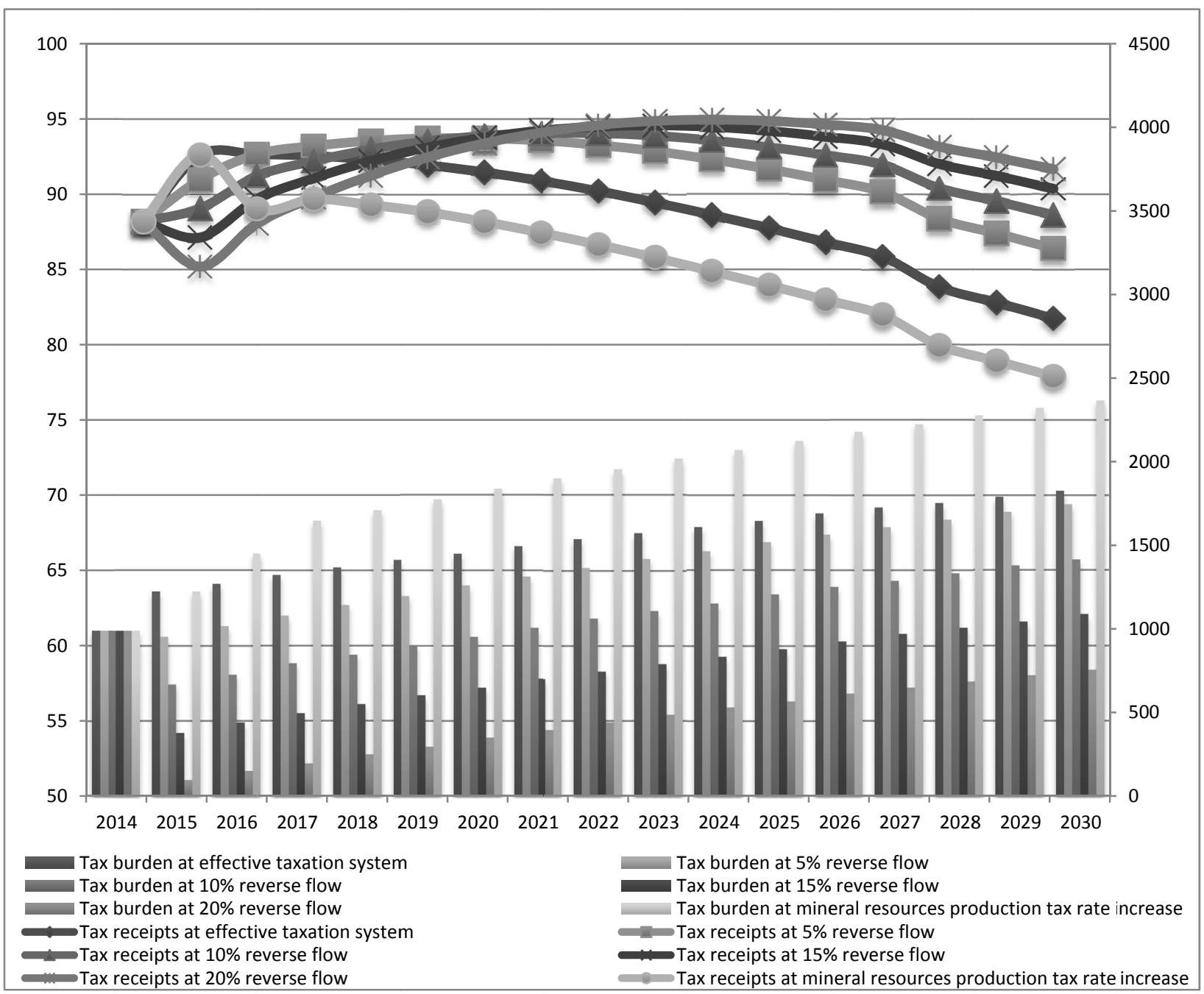

Figure 3. Tax burden according to different oil production scenarios 


\section{Discussion}

The scenario that provides for 5\% decrease of tax burden yields minimum loss of budget receipts in the first year of the calculation period (RUB billion 147) vs. the scenario of oil production under effective taxation system. The former scenario provides also for steady and uniform pumping up the budget for the whole calculation period.

It should be noted that the scenario with mineral resources production tax rate increase (2012-2013) is favourable for the budget in the short term (no lost budget receipts in the first year of the calculation period), however, oil production decline because of reduced innovative funding results in sharp decrease of budget receipts in the long term compared to other modeled scenarios of oil production trends in Russia.

\section{Conclusion}

The scenario that provides for $20 \%$ decrease of tax burden yields the highest total budget receipts (USD 2.4 trillion), however, lost budget receipts in the first year of the calculation period make RUB billion 665 vs. the scenario of oil production under effective taxation system.

By the end of the calculation period, the scenario that provides for $5 \%$ decrease of tax burden closely approximates the scenario of oil production under effective taxation system In terms of budget receipts volumes.

The scenario with mineral resources production tax rate increase is the worst in terms of oil industry growth leading to the industry collapse. According to this scenario, an operating company's tax burden increases to $78 \%$. So far, the world practice has not witnessed economic growth under conditions of taxes as high as this; furthermore, taxation history testifies that too high taxes have not been paid.

In terms of oil industry growth, the scenario that provides for $5 \%$ decrease of tax burden is the most credible and promising, provided the released flows are invested in production. The same level of tax burden decrease (5\%) is required to attain oil production levels in Russia in 2018-2020s according to the 2030 Development Strategy.

\section{References}

Ansoff, I. (1965). Corporate Strategy. McGraw Hill, New York.

BP Statistical Review of World Energy. Retrieved June 25, 2012, from http://bp.com/statisticalreview

Brigham, Yu., \& Gapenski, L. (2004). Financial Management: The Complete Course: In 2 volumes. St. Petersburg: School of Economics, with T.1 (p. 497).

Clower, R. (1995). Economic Doctrine and Method (p. 415).

Drucker, P. (1946). Concept of the Corporation (p. 329). United States. Publisher John Day.

Energy Strategy of Russia for the Period till 2030. Russian Government Executive Order as of 13 Nov 2009. No.1715-p.

Forrester, J. W. (2003). World Dynamics. Translated from English (p. 384). Moscow: ACT, Terra Fantastica.

Ivanter, V. V., \& Ksenofontov, M. Yu. (2012). Concept of Positive Forecast of Russian Economic Growth in the Long Term. Problemy Prognozirovaniya, 6, 4-13.

Knight, F. (1921). Risk, Uncertainty and Profit. N.Y.

Laffer, A. (1979. The Economics of the Tax Revolt: A Reader with Jan P. Seymour.

Lloyd, J. M. (1987). Transportation, Energy and the Future. Translated from English (p. 160). Moscow: Mir.

Mescon, M., Albert, M., \& Khedouri, F. (1997). The basis of Management (p. 704). Moscow: Delo.

Myrdal, G. (1939, March). Fiscal Policy in the Business Cycle. The American Economic Review, 21(1).

North, D. (1997). Institutions, Institutional Change and Economic Performance (p. 180). Translated from English by Nesterenko A. Moscow: Fund of Economic books «Nachala».

Robinson, J. (1956). The Accumulation of Capital. London: Macmillan.

Sharpe, W., Alexander, G., \& Bailey, J. (2001). Investments (p. 1028). Moscow, Infra.

Kikeri, S., Kenyon, T., \& Palmade, V. (2007). Reforming the Investment Climate: Lessons for Practitioners (p. 123). Translated from English by Zaborin N. Moscow: Ves' Mir.

Tinbergen, J. (1956). Economic policy: Principles and design.

World Population in 2011. UNFPA Report. Retrieved from http://gtmarket.ru/news/state/2011/10/31/3701 
Yartiev A. F. (2011). Economic Evaluation of Design Solutions for Capital Investments in Oil Industry (p. 232). Moscow: OAO VNIIOENG.

\section{Copyrights}

Copyright for this article is retained by the author(s), with first publication rights granted to the journal.

This is an open-access article distributed under the terms and conditions of the Creative Commons Attribution license (http://creativecommons.org/licenses/by/3.0/). 